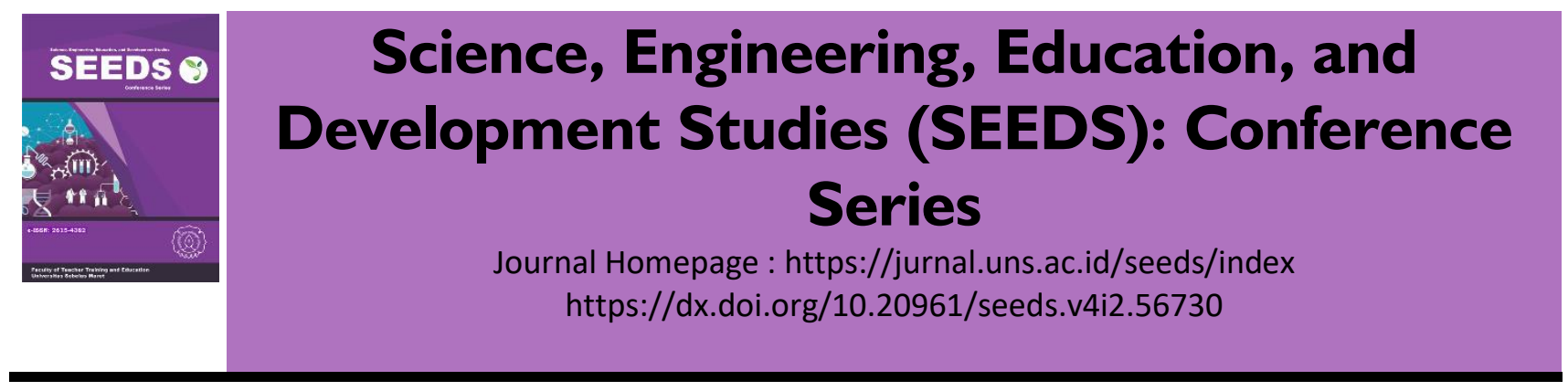

\title{
METODE WINDOW SHOPPING UNTUK MENINGKATKAN HASIL BELAJAR TEKNIK KOMPUTER PADA SISWA KELAS VII SMP NEGERI 6 PONOROGO \\ Yeni Susilo
}

SMP Negeri 6 Ponorogo

Yenisusilo.snapo@gmail.com

Article Info :

Available online $26 / 11 / 2021$

Keywords:

Window shopping

Hasil belajar

Teknik komputer

\section{Abstract}

Kajian ini dilakukan karena hasil belajar teknik komputer peserta didik dalam kegiatan pembelajaran belum optimal. Salah satu solusi untuk memecahkan permasalahan tersebut adalah dengan menerapkan metode pembelajaran window shopping untuk meningkatkan hasil belajar teknik komputer peserta didik. Tujuan kajian ini adalah menjelaskan bagaimana penerapan metode window shopping dalam pembelajaran dapat meningkatkan hasil belajar teknik komputer peserta didik. Dari hasil kajian menunjukkan bahwa hasil belajar teknik komputer peserta didik meningkat secara signifikan dengan penggunaan metode window shopping, aktivitas belajar menjadi lebih menarik sehingga meningkatkan minat peserta didik untuk mengikuti pembelajaran yang diberikan oleh guru 


\section{PENDAHULUAN}

Mata pelajaran TIK/Informatika di tingkat Sekolah Menengah Pertama (SMP) memegang peranan penting untuk mengembangkan kemampuan peserta didik dalam menggunakan Teknologi Informasi dan Komunikasi agar dapat dimanfaatkan untuk kegiatan dan aktivitas sehari hari. Dengan mempelajari TIK peserta didik diharapkan mampu menguasai ilmu pengetahuan dan teknologi sejak dini. Akan tetapi, kendala dalam pembelajaran TIK/Informatika selama ini adalah metode pembelajaran yang digunakan oleh guru masih cenderung menggunakan metode ceramah dalam menyampaikan pelajaran. Hasil study dari Blazely (Sukirno: 2003) menunjukkan bahwa pola atau konsep pembelajaran di SMP masih bersifat teoritis dan cenderung text book oriented. Metode ceramah dalam pembelajaran TIK yang diterapkan selama ini kurang menarik dan tidak sesuai dengan kondisi lingkungan siswa saat ini, sehingga mengakibatkan motivasi siswa menurun dan hasil belajar yang di dapat menjadi tidak optimal. Menurut Hariyanti (2000), masih banyak guru yang kurang kompeten dalam membuat perencanaan pembelajaran, penggunaan media pembelajaran, penerapan metode pembelajaran, dan kurang menguasai materi yang diajarkan sehingga motivasi siswa untuk belajar menjadi berkurang.

Salah satu metode atau model pembelajaran yang dapat diterapkan yaitu model pembelajaran window shopping atau Belanja Ilmu. Metode pembelajaran ini dapat meningkatkan aktivitas belajar peserta didik, sehingga diharapkan akan mampu meningkatnya hasil belajar siswa pada pelajaran informatika. Dalam model pembelajaran window shopping siswa bisa berkunjung dan melihat hasil karya kelompok lain sekaligus mencatat hasil karya kelompok yang dikunjungi dan membagikan hasil catatan tersebut kepada anggota kelompoknya. Dalam window shopping, setiap anggota memiliki tugas dan peran masing-masing. Ada anggota yang bertugas menjaga toko, dan ada anggota yang bertugas melakukan kunjungan ke toko kelompok lain. Sebagai penjaga toko, siswa diharapkan mampu menjelaskan kepada pengunjung dari kelompok lain terkait hasil karya yang ditampilkan (Goeswarno, 2011).

Menurut Dahliardi (2016) metode window shopping sangat mengasyikkan bagi peserta didik karena mereka bisa berkeliling sambil belajar. Peserta didik yang berkeliling dan mengunjungi stand kelompok lain bisa berinteraksi dengan penjaga stand dengan melakukan tanya jawab sehingga mendapatkan tambahan ilmu dan wawasan dari kegiatan Window Shopping tersebut. Sedangkan untuk alokasi waktu dalam kegiatan Window Shopping dilakukan sesuai arahan atau waktu yang ditetapkan oleh guru.

Metode Window Shopping bisa menjadi solusi dalam menerapkan teknik pembelajaran untuk meningkatkan aktivitas dan hasil belajar peserta didik, terutama dalam aspek berfikir kritis dan mencari solusi dalam memecahkan masalah melalui diskusi kelompok dan berani menyampaikan hasil diskusi melalui presentasi, menghargai pendapat teman dan menanggapi hasil presentasi kelompok lain. Hal demikian seperti dinyatakan oleh Rahma (2017), bahwa Window Shopping adalah model pembelajaran berbasis kerja kelompok untuk menambah wawasan dan ilmu pengetahuan dengan berbelanja dan melihat hasil kerja kelompok lain. Dari pemaparan di atas dapat diambil kesimpulan bahwa kegiatan pembelajaran informatika dengan menggunakan metode Window Shopping dapat meningkatkan aktivitas belajar peserta didik dan meningkatkan hasil belajar teknik komputer.

Kelebihan Window Shopping menurut Kurdi (2017) yaitu peserta didik dapat berkunjung dan melihat secara langsung hasil karya kelompok lain sekaligus mencatat hasil karya tersebut untuk dibagikan dengan anggota kelompoknya. Sehingga peserta didik yang berkunjung ke stand/toko kelompok lain sekaligus akan mendapatkan ilmu dan wawasan untuk dibagikan kepada anggota kelompoknya. Dari pemaparan tersebut, dapat diambil kesimpulan bahwa metode window shopping dalam kegiatan pembelajaran dapat melatih peserta didik untuk terbiasa bekerja sama dalam kelompok guna meningkatkan hasil belajar serta membiasakan peserta didik untuk bisa berargumentasi dan berkomunikasi dalam menyampaikan hasil pekerjaan kelompok.

Dari semua pemaparan di atas, maka tujuan dari pelaksanaan kajian ini adalah: (1) ) Meningkatkan aktivitas belajar peserta didik melalui metode pembelajaran Window Shopping; (2) Meningkatkan hasil belajar teknik komputer melalui metode pembelajaran Window Shopping; (3) Menjelaskan pelaksanaan metode pembelajaran Window Shopping pada kegiatan pembelajaran teknik komputer 


\section{HASIL DAN PEMBAHASAN}

\section{Pengertian Window Shopping}

"Window Shopping is the activity of spending time looking at the goods on sale in shop windows without intending to buy any of them" (Cambridge English Dictionary).

Menurut Rahma, W (2017: Jurnal Penelitian Pendidikan Indonesia, Vol. 2, No. 2) Window Shopping adalah model pembelajaran berbasis kerja kelompok dengan melakukan berbelanja keliling melihat-lihat hasil karya kelompok lain untuk menambah wawasannya. Dengan model pembelajaran window shopping (belanja hasil karya) akan dapat menumbuhkan karakter kerjasama, rasa ingin tahu, demokratis, keberanian, dan interaksi peserta didik.

Peserta didik dapat berbelanja ilmu dan wawasan dengan melihat-lihat hasil karya kelompok lain yang dipajang secara kreatif. Masing-masing kelompok menugaskan anggotanya sebagai penjaga toko/stand sementara anggota lainnya berbelanja dengan berkunjung dan melihat hasil karya yang dipajang oleh kelompok lainnya. Dalam kegiatan berkunjung (berbelanja) siswa dapat memberi komentar dan penilaian terhadap hasil karya yang dipajangkan, sehingga akan terjadi interaksi yang dapat mendorong kreativitas siswa dalam berkomunikasi untuk menambah wawasan dari hasil kunjungan tersebut. Metode pembelajaran seperti ini dapat menciptakan suasana yang menyenangkan, kreatif dan efektif untuk mencapai tujuan pembelajaran yang diharapkan.

Kelebihan model pembelajaran ini adalah peserta didik dapat berkeliling dan melihat-lihat hasil karya kelompok lain, berinteraksi dengan aktifitas tanya jawab dengan penjaga stand sekaligus mencatat hasil karya tersebut untuk dibagikan kepada anggota kelompoknya. Sehingga peserta didik yang berkunjung untuk berbelanja akan mendapatkan ilmu dan wawasan sebagai oleh-oleh untuk anggota lainnya terutama anggota yang bertugas sebagai penjaga toko/stand.

\section{Kegiatan Pembelajaran Dengan Metode Window Shopping}

Pada kegiatan pendahuluan, sebelum pembelajaran dimulai guru meminta salah satu peserta didik untuk memimpin Do'a. Guru memeriksa kesiapan siswa dalam mengikuti pelajaran, dan memeriksa absensi kehadiran siswa. Guru memberikan apersepsi dengan mengaitkan materi pembelajaran yang akan dilakukan dengan pengalaman peserta didik pada materi kegiatan sebelumnya. Guru memotivasi siswa dengan mengkondisikan suasana belajar yang menyenangkan membentuk kelompok belajar, menyampaikan tujuan pembelajaran, menyampaikan model pembelajaran yang digunakan dan teknik penilaian yang akan dilakukan. Guru juga menyampaikan materi dan kegiatan pembelajaran yang akan dilaksanakan baik dengan media presentasi maupun dengan video pembelajaran untuk menarik minat siswa dalam mengikuti pembelajaran.

Masuk pada kegiatan inti pembelajaran, pada tahap orientasi, guru membagikan lembar kerja (LKPD) kepada masing-masing kelompok untuk dipelajari terlebih dahulu dengan mengacu kepada buku teks atau modul sebagai sumber utama dan acuan dalam menyelesaikan soal/kasus yang ada di lembar kerja (LKPD). Guru memastikan setiap kelompok memahami tugas yang diberikan dan memberikan kesempatan untuk bertanya terkait tugas yang diberikan.

Pada tahap diskusi, guru membimbing kelompok untuk bisa mengumpulkan informasi yang ada di LKPD, guru memotivasi peserta didik untuk bisa berfikir kritis dalam mencari solusi untuk memecahkan kasus atau masalah berdasarkan informasi yang ditemukan.

Pada langkah mengembangkan dan menyajikan hasil karya, peserta didik menyajikan hasil diskusi kelompoknya ke dalam plano yang telah disediakan. Setelah semua kelompok memajang hasil karyanya, maka dimulailah kegiatan Window Shopping. Selanjutnya guru memberikan petunjuk agar pelaksanaan kegiatan window shopping berjalan lancar sesuai alokasi waktu yang telah ditetapkan. Kegiatan kunjungan (belanja) dibuat bergiliran antar kelompok agar tidak saling berbenturan, kelompok 1 akan berkunjung ke kelompok 2, sedangkan kelompok 2 berkunjung ke kelompok 3, kelompok 3 berkunjung ke kelompok 4 dan seterusnya menyesuaikan jumlah kelompok yang ada. Anggota kelompok yang bertugas melakukan kunjungan (belanja) membawa LKPD hasil diskusi kelompoknya sebagai bahan kunjungan dalam berinteraksi dengan penjaga toko/stand yang dikunjunginya seperti disampaikan oleh Rahma (2017) bahwa kegiatan Window Shopping dapat menjadi sarana bagi peserta didik untuk menambah ilmu dan wawasan dengan berkeliling melihat-lihat hasil karya kelompok lain.

Sejalan dengan pendapat tersebut, Dahliardi (2016) menggambarkan bahwa peserta didik yang berkunjung ke kelompok lain terlihat asyik dan senang karena saat berkunjung, peserta didik berkesempatan melakukan tanya jawab dengan penjaga toko/stand terkait hal-hal yang belum jelas. Dalam kunjungannya 
peserta didik bisa berargumentasi dan mengemukakan pendapat terhadap hasil karya yang dipajang oleh kelompok tersebut. Hal ini sesuai dengan kelebihan metode Window Shopping menurut Kurdi (2017) yaitu peserta didik yang berkunjung dapat melihat-lihat hasil karya kelompok lain, berinteraksi dengan aktifitas tanya jawab dengan penjaga stand sekaligus mencatat hasil karya tersebut untuk dibagikan kepada anggota kelompoknya.

Pada langkah analisis dan evaluasi, berdasarkan hasil observasi terhadap aktivitas peserta didik, kerjasama yang muncul dalam diskusi serta kecepatan dan ketepatan waktu dalam menyelesaikan masalah/kasus yang ada di LKPD, maka guru mengumumkan kelompok terbaik untuk maju ke depan kelas dan mendapatkan reward. Guru menguatkan karakter dengan mendorong peserta didik untuk menghargai prestasi kelompok lain dan memberikan penghargaan berupa applause terhadap keberhasilan yang dicapai. Guru menjadikan kelompok terbaik sebagai motivasi bagi peserta didik untuk berlomba-lomba menjadi yang terbaik pada pertemuan selanjutnya.

Pembelajaran dengan metode Window Shopping ini menjadi sarana bagi peserta didik untuk mengembangkan kemampuan berpikir kritis dalam menyelesaikan permasalahan yang ada di LKPD, melatih kerja sama yang baik dengan teman satu kelompok, berkomunikasi secara santun meskipun terdapat perbedaan pendapat untuk menemukan penyelesaian yang tepat, dan meningkatkan kreativitas agar hasil diskusi yang disajikan di media menarik minat pengunjung kelompok lain serta berlomba-lomba untuk menjadi kelompok terbaik.

Di bagian penutup, guru mengarahkan peserta didik untuk menyimpulkan materi yang telah dibahas pada pertemuan tersebut dan melakukan identifikasi kelebihan dan kekurangan kegiatan pembelajaran yang telah dilaksanakan. Selanjutnya guru memberikan umpan balik kepada peserta didik terhadap hasil pembelajaran dengan memberikan soal evaluasi berupa tes tertulis yang dikerjakan secara individu. Sebagai tindak lanjut, guru menyampaikan kepada peserta didik tentang materi pertemuan berikutnya dan meminta kepada peserta didik untuk belajar mandiri di rumah dengan mengacu pada buku teks, modul maupun dari sumber belajar yang lain. Di bagian akhir kegiatan, guru mengajak peserta didik berdo'a dan memberikan salam untuk menutup kegiatan pembelajaran.

\section{Hasil Kegiatan Pembelajaran}

Meningkatnya hasil belajar peserta didik menunjukkan bahwa metode Window Shopping yang diterapkan dalam kegiatan pembelajaran mampu menarik minat dan mendorong aktivitas belajar peserta didik untuk belajar secara sungguh-sungguh terhadap materi yang diberikan. Seperti diungkapkan oleh Hamalik (2007: 155) bahwa hasil belajar yang diperoleh dapat diukur melalui kemajuan yang diperoleh peserta didik setelah belajar dengan sungguh-sungguh. Pendapat senada juga disampaikan oleh Trianto (2013:16-17) bahwa perubahan pada diri pembelajar adalah perubahan perilaku tetap berupa pengetahuan, pemahaman, keterampilan, dan kebiasaan yang baru diperoleh individu. Hal ini dapat dilihat dari meningkatnya aktivitas belajar peserta didik selama kegiatan pembelajaran berlangsung. Meningkatnya aktivitas belajar tersebut berbanding lurus dengan meningkatnya hasil belajar yang diperoleh peserta didik.

Dari pembahasan kajian ini dapat dinyatakan bahwa penerapan metode pembelajaran Window Shopping dapat meningkatkan hasil belajar peserta didik, meningkatkan aktivitas belajar peserta didik, dan meningkatkan pelaksanaan pembelajaran teknik komputer di kelas VII SMPN 6 Ponorogo.

\section{KESIMPULAN}

Berdasarkan hasil pembahasan kegiatan dapat diambil kesimpulan sebagai berikut:

1. Metode pembelajaran Window Shopping mampu menciptakan suasana kelas yang menyenangkan.

2. Dengan metode pembelajaran Window Shopping, keaktifan dan hasil belajar peserta didik mengalami peningkatan yang cukup signifikan.

3. Seluruh peserta didik ikut terlibat aktif dalam proses pembelajaran sehingga pelaksanaan pembelajaran menjadi lebih baik.

Berdasarkan kesimpulan hasil kajian ini, dikemukakan saran dan rekomendasi sebagai berikut:

1. Peserta didik harus terus terlibat aktif dalam kegiatan pembelajaran, meningkatkan kerja sama kelompok dan berkomunikasi secara intens untuk menemukan langkah-langkah penyelesaian yang tepat agar capaian hasil belajar informatika bisa meningkat.

2. Guru harus lebih kreatif dalam menerapkan metode pembelajaran yang bervariatif untuk menarik minat dan meningkatkan aktivitas belajar siswa. 
3. Memanfaatkan sarana dan lingkungan yang ada di sekolah untuk mengembangkan metode pembelajaran yang bervariatif sesuai karakteristik peserta didik.

\section{DAFTAR PUSTAKA}

Dahliardi. (2016). Menghidupkan Kelas dengan Metode Window Shopping. (Online). dahliardi. blogspot.com> 2016/10. diakses pada 13 November 2021.

Dimyati \& Mudjiono. (2013). Belajar dan Pembelajaran. Jakarta: Rineka Cipta.

Goeswarno. (2011). Model Pembelajaran Window Shopping. (online). https:// goeswarno.blogspot.com/ 2011/11/ model-pembelaran-window-shopping.html?m=1. diakses pada 13 November 2021

Hajar, S. (2018) Penerapan Model Pembelajaran Window Shopping untuk Meningkatkan Kemampuan Koneksi Matematis dan Minat Belajar Siswa. (Online). digilib.uinsgd.ac.id>1_ cover.pdf. Diakses pada 13 November 2021

Hamalik, O. (2009). Proses Belajar Mengajar. Bandung: Bumi Aksara.

Iskandar. (2012). Psikologi Pendidikan. Jakarta: Referensi.

Kementerian Pendidikan dan Kebudayaan. (2016). Panduan Pembelajaran untuk Sekolah Slameto. (2013). Belajar dan Faktor-faktor yang Mempengaruhinya. Jakarta: Rineka Cipta.

Kurdi, M. (2017). Window Shopping: Model Pembelajaran yang Unik dan Menarik. Jurnal Lingkar Widya-iswara, 4, $27-34$.

Menengah Pertama Kurikulum 2013. Jakarta: Kementerian Pendidikan dan Kebudayaan.

Rahma, W. 2017. Pengaruh penggunaan metode kooperatif window shopping terhadap partisipasi bimbingan konseling klasikal. Jurnal Penelitian Pendidikan Indonesia (JPPI) Vol. 2, No. 2, April.

Trianto. (2013). Mendesain Model Pembelajaran Inovatif-Progresif. Jakarta: Prenada Media Group. 